\title{
Analysis of the Present Situation of English Teaching in Higher Vocational Colleges and Its Countermeasures
}

\author{
Jianyong Chen ${ }^{1, a^{*}}$ and Ping Yang ${ }^{2, b}$ \\ ${ }^{1}$ Feixian Campus, Linyi University, China \\ ${ }^{2}$ Xiguan Primary School of Feixian, Shandong province, China \\ afxchenijanyong@163.com, byangping-s@163.com \\ * The corresponding author
}

\begin{abstract}
Keywords: Vocational Colleges and Universities; English Teaching; Current Situation; Countermeasures
\end{abstract}

\begin{abstract}
Higher vocational education bears the responsibility of training application-oriented specialists, and English teaching in higher vocational colleges should emphasize its applicability and practicability. However, higher vocational English teaching in China is faced with the problems of teaching object, teaching content, teaching means and methods, teaching staff and so on. Starting with the problems and present situation of English teaching in vocational colleges, this paper puts forward some countermeasures and suggestions to improve the English teaching quality in vocational colleges.
\end{abstract}

\section{Foreword}

As the most widely used language in the world, English becomes more and more important in the process of economic globalization and education internationalization in the 21 st century. Higher vocational education must be involved in international education competition and cooperation and play an active role in it. This puts forward a new and higher requirement for higher vocational English teaching. However, in most vocational colleges, English teaching still follows the traditional theory indoctrination method of "course translation and instruction + grammar teaching", which emphasizes students' mastery of grammar and language structure, and ignores that communication is the ultimate goal of learning foreign languages. Especially for English learners in vocational colleges, the aim is very clear, to meet the need of foreign language communication in future profession.

Therefore, how to improve teaching, teaching according to the skills, thus improving the English level of higher vocational students and training practical talent for the society have become a common task for higher vocational English teachers. It is the duty of the teachers in the first line of English teaching in vocational colleges to strengthen the research on the present situation of English teaching in vocational colleges, find out the main problems and solutions, and make their own thinking and exploration to change this situation.

\section{Current Situation of English Teaching and Learning in higher Vocational Colleges}

English teaching in higher vocational colleges is an important link in vocational education, but because the English teaching in higher vocational colleges in our country is just beginning and is still in the exploratory stage, the overall situation of English teaching in higher vocational colleges is not optimistic, there are many problems, and the emergence of these problems seriously affects and restricts the healthy development of English teaching in vocational colleges. The present situation of English teaching and learning in higher vocational colleges is as follows:

Aspects of "learning". The quality of students is not uniform and the language is weak. The composition of students in higher vocational colleges is more complicated, there are three kinds of students: one is the college entrance examination scores below the middle level through the general entrance examination; Second, take the higher vocational college entrance examination, from the 
technical school, vocational high school to the higher vocational school students, commonly known as "three school students." Third, junior high school graduates. The overall level of students is relatively low, the diversified structure of source leads to the English level is uneven, individual differences are great.

The goal of learning English is not clear and the attitude of learning is not serious. The English level of students in higher vocational colleges is generally low, some of them have low interest in learning, poor initiative, improper attitude in English learning, unclear purpose, lack of correct learning motivation.

Lack of an environment for language learning and application. English is a highly practical subject, and it is important to learn a simple language well in this language environment. For high school students, the lack of natural language environment, especially in oral learning, can not really feel the charm of English。

Aspects of "teaching". The English teaching mode is backward. The teaching goal of higher vocational colleges is different from that of other colleges. It aims at cultivating students' applied ability. However, English teaching in most vocational colleges in China still follows the traditional single teacher-centered teaching mode, which is a closed traditional mode.

Lack of English teaching facilities. With the development of science and technology,network technology is widely used in classroom teaching, which enriches teaching content and enlivens teaching atmosphere, improves the interest of students. But the ageing of hardware facilities and shortage of it affect the quality and level of English teaching.

The monolithic clutter of English textbooks. At present, there are still some problems in English teaching content in higher vocational colleges, such as the single form, the outdated teaching materials, the emphasis on basic knowledge teaching and the lack of combination of professional teaching.

Teaching staff to be strengthened. Many English teachers in higher vocational colleges are not professional. They have no research into the subject, lack of professional background, lack of practical work exercise and experience accumulation, teaching professional English is more difficult, only stiff translation, can not provide effective guidance for learning and application.

\section{Countermeasures to Change the Present Situation of English Teaching in Higher Vocational Colleges}

With the deepening of English teaching reform in higher vocational colleges, it is imperative to reform English teaching in higher vocational colleges in order to change the present situation of English "teaching" and "learning" and to train applied talents with high comprehensive quality and strong social competitiveness. In view of the requirements of the English syllabus in higher vocational colleges, I put forward a few suggestions for everyone to study together and discuss.

Help students improve their interest in English.Learning interest is the starting point of learning initiative and learning English well. Because of this, teachers have to work hard at stimulating students' interests. Teachers should adopt flexible and varied teaching methods which help to enliven the classroom and stimulate students ' interest. On the one hand, while implementing teaching, teachers should be good at humanizing the classroom management, and properly implement the recognition education law to students, strengthen the encouragement and praise to students. On the other hand, because of the use of multimedia language teaching can make the classroom more information, its content more colorful. Therefore, according to the characteristics of higher vocational students, English teachers can combine the traditional teaching model with the modern teaching model to stimulate the students 'senses, listening, speaking, reading, writing, acting and doing, so that students can devote themselves to teaching activities and stimulate interest and curiosity.

Implementation of Stratified teaching and differentiated teaching. At present, the content, progress and methods of teaching are still carried out by most teachers in the traditional way, without taking into account the special characteristics of students. Ignoring the individual 
differences of students, a standard, a model for all students, it is difficult to realize the principle of teaching according to individual skills. Stratified teaching can make as many students as possible feel the joy of success and reduce Psychological pressure, and help to maximize the learning enthusiasm of students, dig their inner potential. In addition, the stratified teaching can also make teachers optimize the preparation of classes, having classes, assignments, learning methods and other links. It also reduces the burden of students, gives full play to students 'autonomy and helps to improve students' ability to adapt to the future.

Adoption of a diverse student-centred teaching model. English is a kind of communication tool. Learning English is by no means a mere mastery of grammar rules and the use of some words. The key is to actively use learning language knowledge to communicate. Only through systematic study and practice can we master English and achieve the purpose of communication. This requires that the teaching methods of English lessons should be based on communication and emphasize teaching interaction. The purpose of English teaching is to train students to use this kind of communication tool. This requires that the teaching method of English lessons should be communicative and interactive. In the teaching concept, teachers should adhere to "student-centered", do a good job in the transfer of teaching centres, seriously organize teaching, let students play a major role, make efforts to communicate in teaching process, change the old teachers "full of" teaching process, guide students to find problems, solve problems.

Creating an English Language Learning Environment. Creating an English language learning environment is very necessary for students growing up in the Chinese language environment. A large part of this environment depends on students to create and strive for it. In view of the current development of our country, it is not difficult to create and win this learning environment. We now have English language websites, English radio, TV, movies, songs, as well as English speeches, English news and so on.

Constructing a Scientific Assessment System of English. The assessment method of English achievement of higher vocational students must be reformed. The evaluation should focus on the ability of students to communicate in English and the accurate fluency of language communication. First, we should adjust the content of the written examination, reduce the proportion of pure grammar and vocabulary, and focus on the ability of students to apply English to vocational colleges. Secondly, on the basis of written examinations, the proportion of hearing and oral English examinations should be at least 40 percent. In conclusion, we should gradually change the practice of judging students by written test scores, and gradually establish a system of examining students 'comprehensive abilities so as to promote their all-round development

Strengthening the building of teaching staff. Teachers play a leading role in the whole teaching activity. Therefore, strengthening the construction of teachers is the guarantee of enhancing the teaching effect. English teachers in vocational colleges should change their concepts and improve their overall quality continuously so as to meet the requirements of teaching and new situations. Schools should also formulate a set of effective regulations for the management of the teaching staff. Schools should actively provide teachers with opportunities for re-education, to optimize the teacher structure.

\section{Conclusion}

English is a very practical subject, and language practice is the focus of English teaching, is also a necessary means of consolidating knowledge and developing skills. At the same time, The goal of English teaching in higher vocational college is to cultivate students 'applied ability. So under the implementation of the State educational policy"with the purpose of application, mainly practical, enough for the degree", higher professional teachers should train students to have the necessary knowledge of English language, also emphasize on training students to use English. That is, the teachers of schools must combine the teaching of English language and the teaching of English culture in an organic way to help the students to set up a positive learning attitude and learning environment, to consciously guide students' theories to combine with practice and to Let the 
student's English communicative ability get all-around improvement.

At present, higher vocational English teaching in China is facing a new starting point, teachers need to constantly update the teaching concept, content, methods and means, actively participate in, and constantly explore a new higher vocational English teaching road with the goal of training ability and quality. As English teachers in higher vocational colleges, we should be enterprising, unafraid to explore and make bold reforms. The teachers must make a new way of teaching English from the actual needs of the students. Only in this way can we teach vocational English to a new level, really train more qualified and new composite higher vocational and technical personnel who have Strong comprehensive quality and technical ability to meet the needs of the society for the country.

\section{References}

[1] Cheng Guohong. Reflections on English teaching in vocational colleges "J" ChinaAdult education, 2007(10); 184-185.

[2] Chenghong. How to implement layering teaching in English Vocational Education Forum, 2001,(11).

[3] Dengchunmei. Main Problems and Solutions of English Teaching in Vocational Colleges[ J] in National Adult Education, 2009(13); 149.

[4] Sun Yingyue. Thoughts on the Reform of English Teaching in Vocational Colleges. Adult education in China, 2009(14).

[5] Peng L, Fang W. Heterogeneity of Inferring Reputation of Cooperative Behaviors for the Prisoners' Dilemma Game [J]. Physica A: Statistical Mechanics and its Applications, 2015, 433: 367-378. 